\title{
Quantification of the recycling of microbial nitrogen in the rumen using a mechanistic model of rumen fermentation processes
}

\author{
J. DIJKSTRA ${ }^{1 *}$, J. FRANCE ${ }^{2}$ AND S. TAMMINGA ${ }^{1}$ \\ ${ }^{1}$ Wageningen Institute of Animal Sciences WIAS, Animal Nutrition Group, Wageningen Agricultural \\ University, Marijkeweg 40, 6709 PG Wageningen, The Netherlands \\ ${ }^{2}$ Institute of Grassland and Environmental Research, North Wyke Research Station, Okehampton, Devon, \\ EX20 2SB, UK \\ (Revised MS received 27 January 1997)
}

\begin{abstract}
SUMMAR Y
The effects of dietary variations on microbial $\mathrm{N}$ turnover and recycling related to protozoal activities in the rumen were examined using a previously described model of rumen fermentation processes. Simulations were performed with diets containing variable proportions of concentrate (between 0 and $1 \mathrm{~kg} / \mathrm{kg}$ diet dry matter) at a rate of daily dry matter intake (DMI) by cattle of between $5 \cdot 3$ and $21.0 \mathrm{~kg} / \mathrm{day}$. The roughages examined were hay, fresh grass and maize silage, and the concentrate supplements included molasses, barley, maize grain, untreated and formaldehyde-treated soyabean meal. The simulated fractional turnover rate of microbial $\mathrm{N}$ varied between 0.416 and $1.556 /$ day, and simulated microbial $\mathrm{N}$ recycling ranged from 34.9 to $76.2 \%$ of gross microbial $\mathrm{N}$ synthesis. High turnover rates and recycling were observed particularly for diets containing maize silage as roughage and molasses and maize grain as concentrate supplements. Increased DMI generally resulted in reduced turnover rates with high-roughage diets, but increased turnover rates with high-concentrate diets. These responses of microbial $\mathrm{N}$ turnover and recycling were related to substrate availability and the substrate preferences of protozoa and, consequently, protozoal activities in the rumen. The large impact of recycling on the amount of organic matter required per unit of microbial protein washed out of the rumen was demonstrated. Thus, by quantification of the interactions between microbial populations in the rumen, the model can help to interpret the differences in microbial $\mathrm{N}$ recycling observed in the experiments and provide an improved understanding of the efficiency of microbial protein synthesis.
\end{abstract}

\section{INTRODUCTION}

Microbial protein reaching the duodenum is the major component of duodenal protein in ruminants, accounting for $>50 \%$ of the total duodenal protein flow. The amount of microbial protein washed out of the rumen is influenced by a number of dietary factors (see review by Clark et al. (1992)). However, a variable part of the ruminally synthesised microbial protein does not reach the duodenum, but is recycled within the rumen (review Firkins 1996). This recycling of microbial matter is extensive and affects the efficiency of conversion of feed substrates into microbial protein, because energy is required for the

* To whom all correspondence should be addressed. Email: jan.dijkstra@alg.vv.wau.nl re-synthesis of microbial protein and degraded microbial protein is subject to deamination (Hespell \& Bryant 1979). The causes of recycling of microbial material in the rumen include lysis of microbial cells due to infection by bacteriophages (Klieve \& Bauchop 1988) or by mycoplasmas (Robinson \& Hungate 1973), lysis of cells related to substrate deprivation (Mink \& Hespell 1981) or to substrate excess resulting in accumulation of fermentation endproducts (Prins \& Van Hoven 1977), and engulfment of microorganisms by protozoa (Coleman \& Sandford 1979). The extent of microbial recycling due to infection or due to substrate deprivation remains to be quantified. Recycling due to protozoal activities is more extensively documented. In vitro, the turnover of bacteria due to predation by protozoa was high (up to $100 \% /$ day) (Coleman \& Sandford 1979). The breakdown of bacterial protein was reduced by $c$. 
$90 \%$ upon removal of protozoa (Wallace \& McPherson 1987; Newbold \& Hillman 1990; Sharp et al. 1994). In vivo, defaunation of the rumen increased the efficiency of microbial protein synthesis profoundly (review Jouany et al. 1988). Some $65-85 \%$ of protozoa are recycled within the rumen due to autolysis (reviewed by Leng 1989). Although there is considerable basic knowledge of protozoal metabolism, in vivo data on the amounts of microbial material recycled within the rumen due to protozoa and on dietary factors affecting this recycling are scarce. Dijkstra (1994) developed a mechanistic rumen model that incorporated predation of micro-organisms and autolysis of protozoa. The aim of the present study was to quantify ruminal recycling of microbial nitrogen $(\mathrm{N})$ resulting from protozoal activities using this model of rumen fermentation processes, and to examine the effects of dietary factors on microbial $\mathrm{N}$ recycling in cattle.

\section{MATERIALS AND METHODS \\ General description of the model}

A full description of the model used in this study has been presented previously (Dijkstra et al. 1992; Dijkstra 1994). A simplified diagram of the model and the fluxes representing recycling of microbial $\mathrm{N}$ due to protozoal metabolism is given in Fig. 1. The model's 19 state variables relate to carbohydrate entities (fibre, starch and sugars), non-microbial N-containing entities (protein and ammonia), fatty acid-containing entities (lipid and volatile fatty acids) and microbial entities (amylolytic bacteria, fibrolytic bacteria, and protozoa). The majority of the fluxes between state variables and into and out of the system are represented using standard saturation expressions from enzyme kinetics (Michaelis-Menten equations). The remainder are described by mass-action forms. Parameters in the equations were assigned values based on stoichiometric relationships and on results of appropriate experiments, where available. Alternatively, parameters were assigned values on a priority basis. To illustrate the latter, the affinity parameter in the transaction feed starch to protozoal storage starch was assigned a lower value than that in the transaction feed starch to protozoal non-storage starch metabolism, based on observations that starch can rapidly be engulfed and stored within the protozoal cell to be fermented several hours later (Williams \& Coleman 1988). A full description of parameterization can be found elsewhere (Dijkstra et al. 1992; Dijkstra 1994). The model is driven by continuous inputs of nutrients, calculated from the amount of offered feed and the chemical composition of the diet. It is programmed in ACSL (Advanced Continuous Simulation Language;

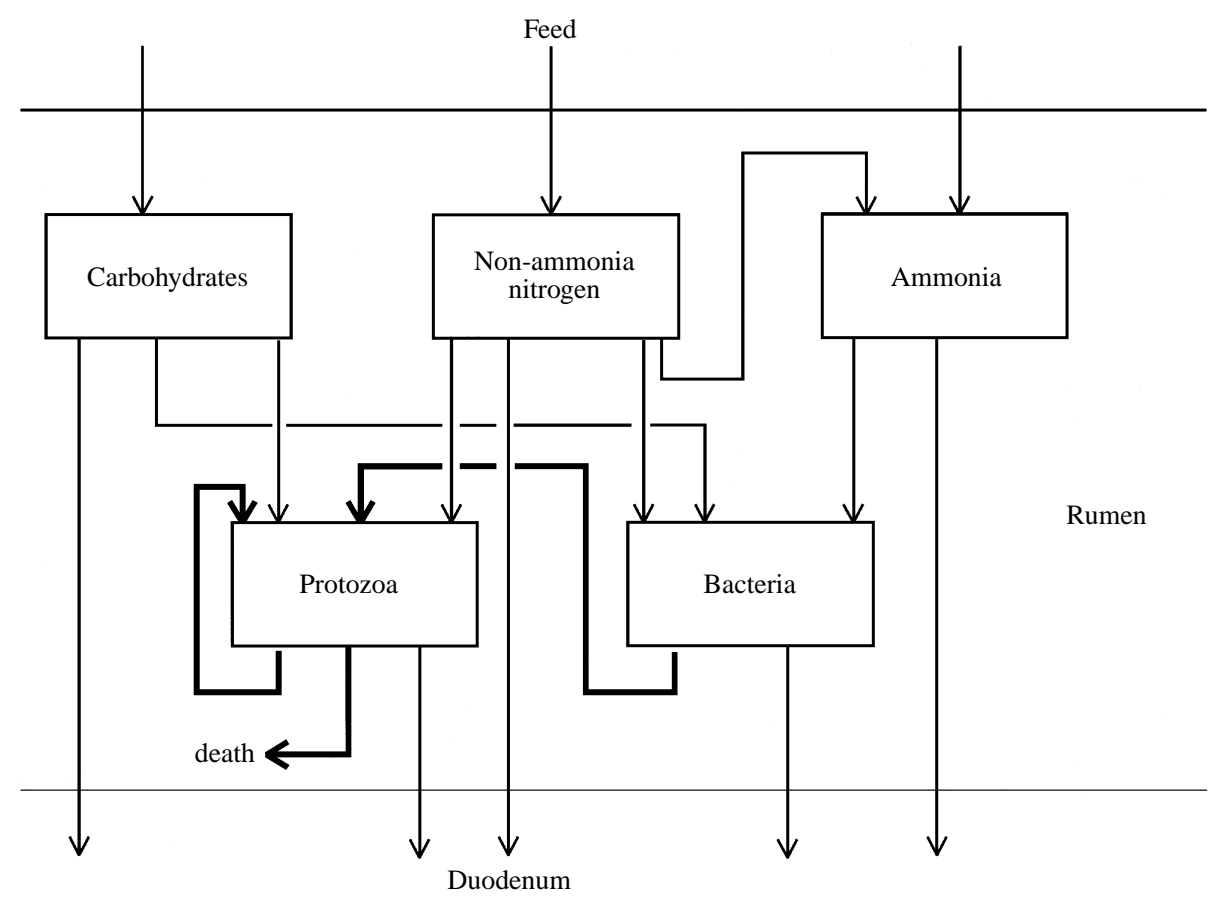

Fig. 1. Simplified diagrammatic representation of the rumen model. Boxes enclosed by solid lines indicate state variables and arrows indicate fluxes; bold arrows indicate fluxes which contribute to microbial $\mathrm{N}$ turnover and recycling. 
Table 1. Chemical composition $(\mathrm{g} / \mathrm{kg}$ dry matter $(D M))$ of the dietary ingredients used in simulations

\begin{tabular}{|c|c|c|c|c|c|c|c|c|c|}
\hline & Hay* & $\begin{array}{c}\text { Mixed } \\
\text { concentrate }\end{array}$ & Grass & $\begin{array}{l}\text { Maize } \\
\text { silage }\end{array}$ & Molasses & $\begin{array}{l}\text { Barley } \\
\text { grain }\end{array}$ & $\begin{array}{l}\text { Maize } \\
\text { grain }\end{array}$ & $\begin{array}{l}\text { Untreated } \\
\text { soyabean } \\
\text { meal }\end{array}$ & $\begin{array}{l}\text { Formaldehyde- } \\
\text { treated } \\
\text { soyabean meal }\end{array}$ \\
\hline $\begin{array}{l}\text { Neutral detergent } \\
\text { fibre }\end{array}$ & 520 & 355 & 425 & 390 & 0 & 220 & 122 & 154 & 154 \\
\hline Soluble sugars & 160 & 68 & 152 & 10 & 700 & 15 & 12 & 107 & 107 \\
\hline Starch & 0 & 197 & 0 & 240 & 0 & 600 & 724 & 11 & 11 \\
\hline Crude fat & 23 & 31 & 23 & 30 & 0 & 13 & 40 & 16 & 16 \\
\hline Total nitrogen & $21 \cdot 7$ & $28 \cdot 9$ & $29 \cdot 4$ & $15 \cdot 3$ & $8 \cdot 8$ & $18 \cdot 0$ & $16 \cdot 5$ & $89 \cdot 3$ & $89 \cdot 3$ \\
\hline
\end{tabular}

* Adopted from Robinson et al. (1986).

Mitchell \& Gauthier 1981) and solved by integration of the 19 state variables using a fourth-order RungaKutta method (France \& Thornley 1984).

\section{Representation of protozoal metabolism and microbial recycling}

In the model, the main source of energy supply for protozoa was considered to be carbohydrates, with preference for utilization of starch and sugars compared to fibre (Williams \& Coleman 1988; Jouany 1989). The main source of $\mathrm{N}$ was protein, either feed protein or microbial protein available upon engulfment. Utilization of insoluble protein was preferred by protozoa to that of soluble protein (Forsberg et al. 1984; Wallace \& Cotta 1988) and, unlike bacteria, ammonia was assumed not to be used to synthesise amino acids (Jouany et al. 1988). A part of the starch and sugars taken up by protozoa was stored (Coleman 1992). Protozoa were assumed to be washed out of the rumen slowly (Faichney 1989).

The processes that contribute to the recycling of microbial matter which have been represented in the model are: engulfment of amylolytic and fibrolytic bacteria by protozoa; engulfment of protozoa by other protozoa; lysis of protozoal cells related to substrate availability. The uptake of bacteria and protozoa was represented by Michaelis-Menten equations similar to the rectangular hyperbola proposed by Holling (1959) to represent predation rate, with parameters as described previously (Dijkstra et al. 1992). This representation assumes that, at low concentrations of microbes, protozoa would search thoroughly to secure an adequate uptake of microbial matter, whereas at high microbial concentrations, protozoa would reduce their search efforts because of satiation. Amylolytic and fibrolytic bacteria were considered to be engulfed in the proportion in which they were present. This is based on experimental observations which indicate that, although selective engulfment of bacteria by some protozoal species might occur, no consistent pattern between protozoal species could be found (review Coleman 1989). Uptake of micro-organisms was assumed to be reduced due to the presence of starch within the protozoa (Coleman 1975, 1992). This was represented by a sigmoidal function similar to Hill's equation in enzyme kinetics, based on observations that bacterial uptake rate was not limited when protozoa were filled with relatively small amounts of starch, whereas engulfment of bacteria was never completely inhibited, even when protozoa appeared to be completely filled with starch (Coleman 1975). Lysis of protozoal cells was related to substrate availability as follows. Particularly on diets rich in easily degradable carbohydrates, protozoa have been observed to degenerate and burst (Williams \& Coleman 1988), probably because of an intracellular accumulation of acidic fermentation products (Prins \& Van Hoven 1977). Thus, in the model, a sigmoidal relationship was assumed between protozoal death rate and the relative amount of volatile fatty acids produced from substrate fermentation within the protozoa.

\section{Dietary inputs}

The simulations to quantify the recycling of rumen microbial $\mathrm{N}$ were conducted for dairy cows. They were designed to study the effect of rate of daily dry matter intake (DMI, $\mathrm{kg} /$ day), variations in the concentrate proportion of the diet, and variations in the composition of the roughage and the concentrate used. Initial values were based on the results of Robinson et al. (1986, 1987). In this experiment, dairy cows were fed ryegrass hay-concentrate (HC) diets $(1: 2, \mathrm{w} / \mathrm{w})$ at various rates of daily DMI $(5 \cdot 3,9 \cdot 2$, $13 \cdot 1,17 \cdot 1$ and $21 \cdot 0 \mathrm{~kg} /$ day). Fluid and solid passage rates, rumen volume and rumen fluid $\mathrm{pH}$ at different daily DMI were taken from Robinson et al. (1986, 1987). The chemical composition of the hay and the concentrate is given in Table 1. Estimates of soluble and undegradable fractions and digestion turnover times were calculated as described previously (Dijkstra et al. 1992). The effect of roughage:concentrate ratio 


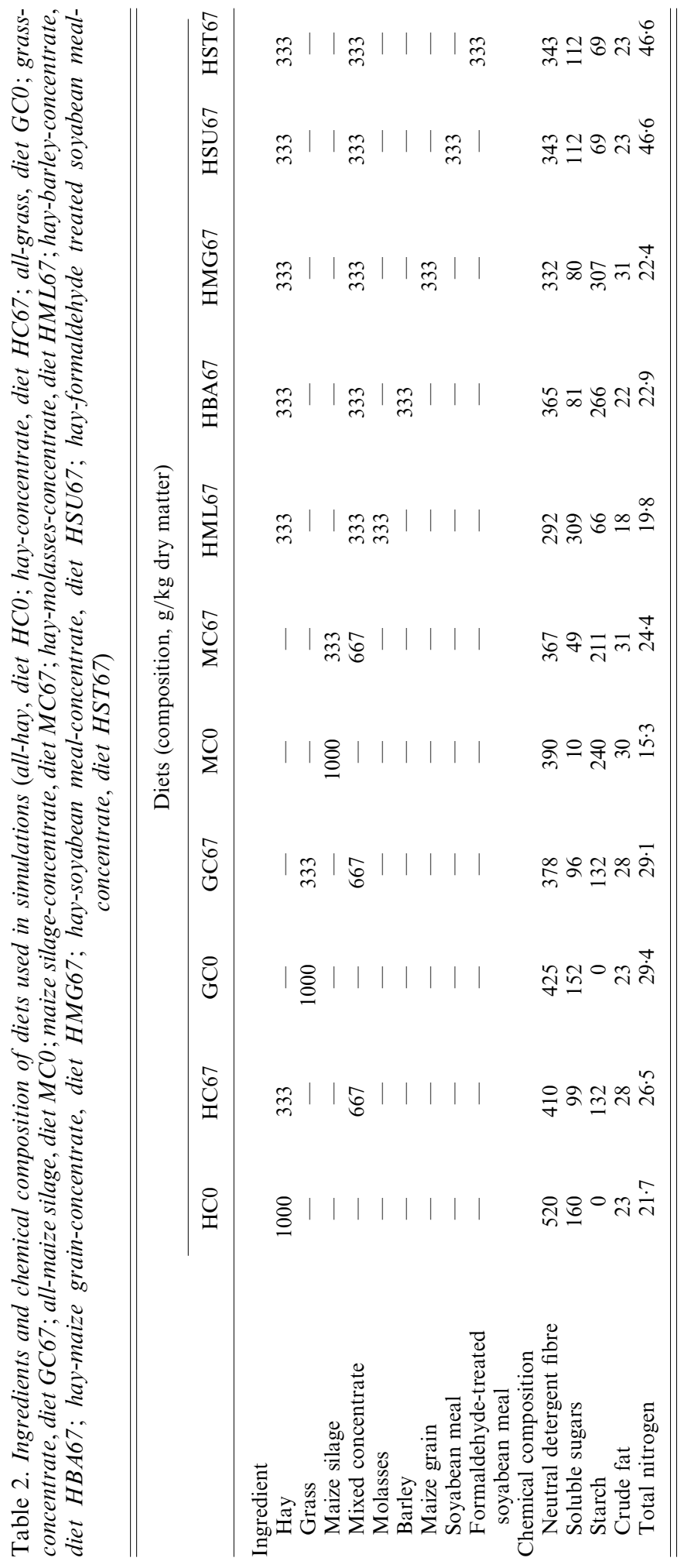


Table 3. The simulated effect of daily dry matter intake on ruminal protozoal nitrogen $(N)$ and total microbial $N$ mass, on duodenal microbial $N$ flow, and on microbial $N$ turnover and recycling in the rumen of cattle fed a hayconcentrate $(1: 2, w / w)$ diet (diet HC67)

\begin{tabular}{|c|c|c|c|c|c|}
\hline & \multicolumn{5}{|c|}{ Daily dry matter intake (kg/day) } \\
\hline & $5 \cdot 3$ & $9 \cdot 2$ & $13 \cdot 1$ & $17 \cdot 1$ & $21 \cdot 0$ \\
\hline $\begin{array}{l}\text { Rumen protozoal } \mathrm{N} \\
\text { mass }(\mathrm{g} \mathrm{N})\end{array}$ & $20 \cdot 1$ & $28 \cdot 5$ & $35 \cdot 5$ & $35 \cdot 9$ & $41 \cdot 6$ \\
\hline $\begin{array}{l}\text { Rumen microbial } \mathrm{N} \\
\text { mass }(\mathrm{g} \mathrm{N})\end{array}$ & $90 \cdot 5$ & $120 \cdot 9$ & $168 \cdot 6$ & $172 \cdot 0$ & $224 \cdot 9$ \\
\hline $\begin{array}{l}\text { Duodenal flow of } \\
\text { microbial } \mathrm{N}(\mathrm{g} \mathrm{N} / \text { day })\end{array}$ & $68 \cdot 3$ & $116 \cdot 4$ & $170 \cdot 0$ & $215 \cdot 1$ & $265 \cdot 1$ \\
\hline $\begin{array}{l}\text { Microbial N turnover } \\
\text { (g N/day) }\end{array}$ & $50 \cdot 6$ & $85 \cdot 9$ & $134 \cdot 0$ & $145 \cdot 0$ & $190 \cdot 2$ \\
\hline $\begin{array}{l}\text { Fractional microbial } \mathrm{N} \\
\text { turnover (per day) }\end{array}$ & $0 \cdot 559$ & $0 \cdot 711$ & $0 \cdot 795$ & $0 \cdot 843$ & $0 \cdot 846$ \\
\hline $\begin{array}{l}\text { Microbial N recycling } \\
(\%)\end{array}$ & $42 \cdot 6$ & $42 \cdot 5$ & $44 \cdot 2$ & $40 \cdot 3$ & $41 \cdot 8$ \\
\hline
\end{tabular}

at low to high daily DMI was investigated using the same hay and concentrate, with proportions of concentrate dry matter (DM) set at $0(\mathrm{HC} 0), 333$ (HC33), 667 (HC67) and 1000 (HC100) g/kg diet DM. Changes in fluid and solid passage rates were estimated according to the relative changes calculated using the regression equations reported by Owens \& Goetsch (1986). For each DMI, pH values of diets $\mathrm{HC} 0, \mathrm{HC} 33$ and $\mathrm{HC} 100$ were $0 \cdot 2$ and $0 \cdot 1$ units higher and $0 \cdot 1$ unit lower than the corresponding value for diet HC67 as given by Robinson et al. (1987) and discussed previously (Dijkstra \& Tamminga 1995).

To examine the effect of type of roughage, simulations were performed for the diets with roughage: concentrate ratios of 100:0 and 33:67, in which the hay was replaced by fresh grass (diets GC0 and GC67) or by maize silage (diets MC0 and MC67) at daily DMI of $9 \cdot 2$ and $17 \cdot 1 \mathrm{~kg} \mathrm{DM} /$ day. The composition of the grass and the maize silage is given in Table 1, adopted from various sources along the guidelines described by Dijkstra et al. (1992). The concentrate used in the experiment of Robinson et al. (1986) consisted of by-products, characterized by a relatively high fibre content and a low starch and sugar content. Therefore, in further simulations with hay $(333 \mathrm{~g} / \mathrm{kg}$ diet DM) as sole roughage, $50 \%$ of this high-fibre concentrate was replaced by ingredients containing increased soluble sugars (molasses; diet HML67), rapidly degradable starch (barley; diet HBA67), slowly degradable starch (maize grain; diet HMG67), rapidly degradable protein (untreated soyabean meal; diet HSU67) and slowly degradable protein (formaldehyde-treated soyabean meal; diet HST67). Again, these simulations were performed at daily DMIs of $9 \cdot 2$ and $17 \cdot 1 \mathrm{~kg} \mathrm{DM} /$ day. The chemical composition of these feed ingredients is given in Table
1 , and the ingredients and composition of all diets is given in Table 2 . When replacing hay by grass or maize silage, and replacing part of the concentrate by other ingredients, the fractional passage rate values for the corresponding original diet were applied.

\section{Calculation of microbial turnover and recycling}

In the model, the microbial $\mathrm{N}$ content per unit of polysaccharide-free microbial dry matter (PFMDM) was fixed $(0 \cdot 118 \mathrm{~g} \mathrm{~N} / \mathrm{g}$ PFMDM). The model predicts amongst other things the steady-state rumen pool size $\left(Q_{\mathrm{i}}, \mathrm{g}\right.$ PFMDM) of amylolytic bacteria $\left(Q_{\mathrm{Ba}}\right)$, fibrolytic bacteria $\left(Q_{\mathrm{Bf}}\right)$, and protozoa $\left(Q_{\mathrm{Po}}\right)$. Also, the steady state fluxes $\left(U_{i, j k}\right.$, rate of utilization of $i$ by $j-k$ transaction, g PFMDM/day) of amylolytic bacteria engulfed by protozoa $\left(U_{\mathrm{Ba}, \mathrm{BaPo}}\right)$, fibrolytic bacteria engulfed by protozoa $\left(U_{\mathrm{Bf}, \mathrm{BfP}}\right)$, protozoa engulfed by other protozoa $\left(U_{\mathrm{Po}, \mathrm{PoP} O}\right)$, and death and lysis of protozoa $\left(U_{\mathrm{Po}, \mathrm{PoDe}}\right)$, and from rumen into omasum of amylolytic $\left(U_{\mathrm{Ba}, \mathrm{BaEx}}\right)$ and fibrolytic bacteria $\left(U_{\mathrm{Bf}, \mathrm{BfEx}}\right)$ and of protozoa $\left(U_{\mathrm{Po}, \mathrm{PoEx}}\right)$ are predicted. Thus, the turnover of microbial material in the rumen related to protozoal activities ( $\mathrm{g}$ microbial $\mathrm{N} /$ day) can be calculated as:

$$
\begin{aligned}
\text { Turnover }=0 \cdot 118\left[U_{\mathrm{Ba}, \mathrm{BaPo}}+U_{\mathrm{Bf}, \mathrm{BfPo}}\right. & \\
& \left.+U_{\mathrm{Po}, \mathrm{PoP} \mathrm{Po}}+U_{\mathrm{Po}, \mathrm{PoDe} e}\right]
\end{aligned}
$$

The fractional turnover rate of microbial $\mathrm{N}$ (per day) is then calculated as:

$$
\begin{aligned}
& \text { Fractional } \\
& \text { turnover } \\
& \text { rate }
\end{aligned}=\frac{\text { Turnover }}{0 \cdot 118\left(Q_{\mathrm{Ba}}+Q_{\mathrm{Bf}}+Q_{\mathrm{Po}}\right)}
$$

The ruminal recycling of microbial $\mathrm{N}(\%)$ in steady 

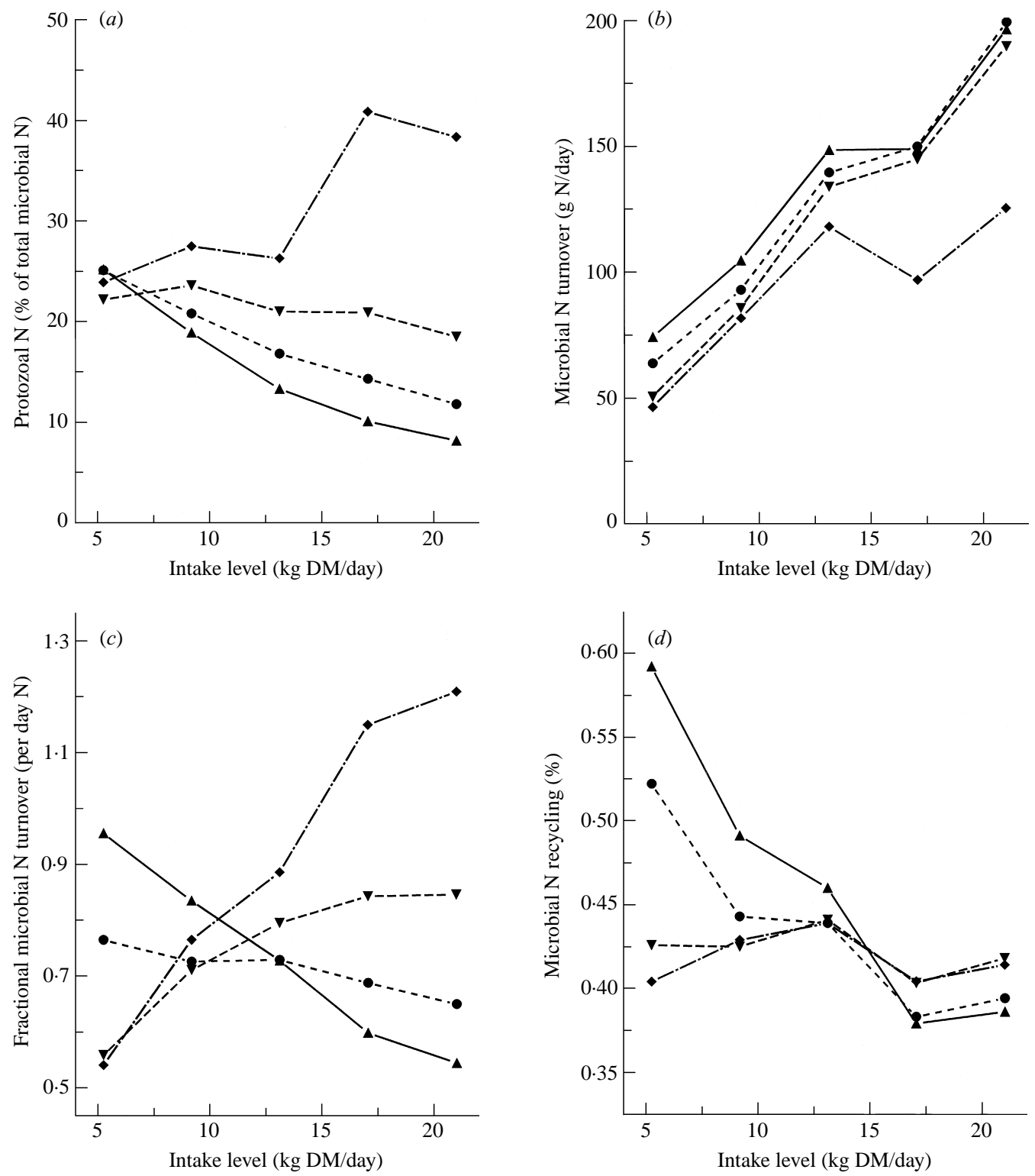

Fig. 2. Predicted effect on $(a)$ protozoal nitrogen $(\mathrm{N})$ in total microbial $\mathrm{N}$ mass in the rumen, $(b)$ microbial $\mathrm{N}$ turnover, $(c)$ fractional microbial $\mathrm{N}$ turnover, and $(d)$ microbial $\mathrm{N}$ recycling, of daily dry matter intake (DMI) of diets containing $0(\boldsymbol{\Delta})$, $333(\bullet), 667(\boldsymbol{\nabla})$ or $1000(\diamond) \mathrm{g}$ concentrate DM/kg diet DM. For details of diets, see Table 1.

state represents the proportion of microbial $\mathrm{N}$ synthesised but not washed out of the rumen and is given by:

Recycling $=$

$\frac{\text { Turnover }}{\left[\text { Turnover }+0 \cdot 118\left(U_{\mathrm{Ba}, \mathrm{BaEx}}+U_{\mathrm{Bf}, \mathrm{BfEx}}+U_{\mathrm{Po}, \mathrm{PoEx}}\right)\right]}$
$\times 100(\%)$

\section{RESULTS}

Effect of daily DMI and concentrate proportion

The simulated rumen microbial and protozoal $\mathrm{N}$ increased with an increase in daily DMI (Table 3). Microbial $\mathrm{N}$ turnover related to protozoal activities was $50.6 \mathrm{~g} /$ day at the lowest daily DMI, and $190 \cdot 2 \mathrm{~g} /$ day at the highest daily DMI. Thus, the fractional microbial $\mathrm{N}$ turnover rate increased from 
Table 4. The simulated rumen protozoal nitrogen $(N)$ and total microbial $N$ mass, duodenal microbial $N$ flow, and microbial $N$ turnover and recycling in the rumen of cattle fed hay (diet HCO), grass (diet GCO), maize silage (diet MC0), hay-concentrate $(1: 2, w / w$; diet HC67), grass-concentrate $(1: 2, w / w ;$ diet GC67), or maize silageconcentrate $(1: 2, w / w$; diet MC67) at a dry matter intake of $9 \cdot 2 \mathrm{~kg} /$ day

\begin{tabular}{|c|c|c|c|c|c|c|}
\hline & \multicolumn{6}{|c|}{ Diet } \\
\hline & $\mathrm{HC} 0$ & $\mathrm{GC} 0$ & $\mathrm{MC} 0$ & HC67 & GC67 & MC67 \\
\hline $\begin{array}{l}\text { Rumen protozoal } \mathrm{N} \\
\text { mass }(\mathrm{g} \mathrm{N})\end{array}$ & $23 \cdot 7$ & $22 \cdot 6$ & $46 \cdot 9$ & $28 \cdot 5$ & $27 \cdot 8$ & $36 \cdot 0$ \\
\hline $\begin{array}{l}\text { Rumen microbial } \mathrm{N} \\
\text { mass }(\mathrm{g} \mathrm{N})\end{array}$ & $125 \cdot 5$ & $132 \cdot 7$ & $88 \cdot 5$ & $120 \cdot 9$ & $125 \cdot 6$ & $108 \cdot 3$ \\
\hline $\begin{array}{l}\text { Duodenal flow of } \\
\text { microbial } \mathrm{N}(\mathrm{g} \mathrm{N} / \text { day })\end{array}$ & $108 \cdot 7$ & $117 \cdot 5$ & $56 \cdot 7$ & $116 \cdot 4$ & $122 \cdot 5$ & $101 \cdot 2$ \\
\hline $\begin{array}{l}\text { Microbial N turnover } \\
\text { (g N/day) }\end{array}$ & $104 \cdot 8$ & $103 \cdot 3$ & $121 \cdot 9$ & $85 \cdot 9$ & $84 \cdot 2$ & $87 \cdot 8$ \\
\hline $\begin{array}{l}\text { Fractional microbial } \mathrm{N} \\
\text { turnover (per day) }\end{array}$ & 0.835 & 0.778 & $1 \cdot 377$ & 0.711 & 0.670 & 0.811 \\
\hline $\begin{array}{l}\text { Microbial N recycling } \\
(\%)\end{array}$ & $49 \cdot 1$ & $46 \cdot 8$ & $68 \cdot 3$ & $42 \cdot 5$ & $40 \cdot 7$ & $46 \cdot 5$ \\
\hline
\end{tabular}

Table 5. The simulated rumen protozoal nitrogen $(N)$ and total microbial $N$ mass, duodenal microbial $N$ flow, and microbial $N$ turnover and recycling in the rumen of cattle fed hay (diet HCO), grass (diet GCO), maize silage (diet MC0), hay-concentrate $(1: 2, w / w$; diet HC67), grass-concentrate $(1: 2, w / w$; diet GC67), or maize silageconcentrate $(1: 2, w / w ;$ diet MC67) at a dry matter intake of $17 \cdot 1 \mathrm{~kg} /$ day

\begin{tabular}{|c|c|c|c|c|c|c|}
\hline & \multicolumn{6}{|c|}{ Diet } \\
\hline & $\mathrm{HC} 0$ & $\mathrm{GC} 0$ & $\mathrm{MC} 0$ & HC67 & GC67 & MC67 \\
\hline $\begin{array}{l}\text { Rumen protozoal } \mathrm{N} \\
\text { mass }(\mathrm{g} \mathrm{N})\end{array}$ & $25 \cdot 2$ & $25 \cdot 3$ & $46 \cdot 6$ & $35 \cdot 9$ & $35 \cdot 6$ & $40 \cdot 6$ \\
\hline $\begin{array}{l}\text { Rumen microbial } \mathrm{N} \\
\text { mass }(\mathrm{g} \mathrm{N})\end{array}$ & $249 \cdot 5$ & $248 \cdot 0$ & $150 \cdot 3$ & $172 \cdot 0$ & $181 \cdot 6$ & $150 \cdot 4$ \\
\hline $\begin{array}{l}\text { Duodenal flow of } \\
\text { Microbial N (g N/day) }\end{array}$ & $244 \cdot 0$ & $260 \cdot 2$ & $117 \cdot 9$ & $215 \cdot 1$ & $228 \cdot 1$ & $192 \cdot 5$ \\
\hline $\begin{array}{l}\text { Microbial N turnover } \\
\text { (g N/day) }\end{array}$ & $149 \cdot 1$ & $148 \cdot 5$ & $234 \cdot 2$ & $145 \cdot 0$ & $145 \cdot 5$ & $147 \cdot 3$ \\
\hline $\begin{array}{l}\text { Fractional microbial } \mathrm{N} \\
\text { turnover (per day) }\end{array}$ & 0.599 & 0.597 & $1 \cdot 556$ & $0 \cdot 843$ & $0 \cdot 803$ & 0.980 \\
\hline $\begin{array}{l}\text { Microbial N recycling } \\
(\%)\end{array}$ & $37 \cdot 9$ & $36 \cdot 3$ & $66 \cdot 5$ & $40 \cdot 3$ & $38 \cdot 9$ & $43 \cdot 3$ \\
\hline
\end{tabular}

$0.559 /$ day to $0 \cdot 846 /$ day, respectively. The recycling of microbial $\mathrm{N}$ in the rumen on this diet, however, hardly changed with daily DMI (between $40 \cdot 3$ and $44.2 \%$ of gross microbial $N$ synthesis), because the increase in microbial $\mathrm{N}$ turnover was accompanied by an increased duodenal outflow of microbial $\mathrm{N}$ (from $68 \cdot 3$ to $265 \cdot 1 \mathrm{~g} \mathrm{~N} /$ day at the lowest and highest daily DMI, respectively).

The simulated proportion of protozoal $\mathrm{N}$ in total microbial $\mathrm{N}$ in the rumen was generally predicted to decline with an increase in daily DMI, the decline being larger as the roughage proportion of the diet was increased, except for diet HC100 (Fig. 2a). Intake of this all-concentrate diet at a rate exceeding $15 \mathrm{~kg}$ $\mathrm{DM} /$ day gave rise to the elimination of fibrolytic bacteria. This elimination was the result of the relatively low amount of substrate available, the low $\mathrm{pH}$ of rumen fluid, and the high fractional outflow rate. Increasing daily DMI generally gave rise to higher microbial $\mathrm{N}$ turnover in the rumen (Fig. $2 b$ ). In response to increases in daily DMI, the fractional turnover rate decreased when the concentrate proportion was low (from $0.956 /$ day at $5.3 \mathrm{~kg} \mathrm{DM} /$ day to $0.545 /$ day at $21.0 \mathrm{~kg} \mathrm{DM} /$ day with diet $\mathrm{HC} 0$ ), yet increased when the concentrate proportion was high (from $0 \cdot 541 /$ day at $5 \cdot 3 \mathrm{~kg} \mathrm{DM} /$ day to $1 \cdot 210$ /day at 
Table 6. The simulated rumen protozoal nitrogen $(N)$ and total microbial $N$ mass, duodenal microbial $N$ flow, and microbial $N$ turnover and recycling in the rumen of cattle fed hay-concentrate $(1: 2, w / w$; diet HC67), haymolasses-concentrate $(1: 1: 1, w / w ;$ diet HML67), hay-barley-concentrate $(1: 1: 1, w / w ;$ diet HBA67), hay-maize grain-concentrate $(1: 1: 1, w / w$; diet HMG67), hay-soyabean meal-concentrate $(1: 1: 1, w / w$; diet HSU67) or hayformaldehyde treated soyabean meal-concentrate $(1: 1: 1, w / w$; diet HST67) at a dry matter intake of 9.2 $\mathrm{kg} /$ day

\begin{tabular}{|c|c|c|c|c|c|c|}
\hline & \multicolumn{6}{|c|}{ Diet } \\
\hline & HC67 & HML67 & HBA67 & HMG67 & HSU67 & HST67 \\
\hline $\begin{array}{l}\text { Rumen protozoal } \mathrm{N} \\
\text { mass }(\mathrm{g} \mathrm{N})\end{array}$ & $28 \cdot 5$ & $26 \cdot 9$ & $36 \cdot 5$ & $44 \cdot 2$ & $24 \cdot 4$ & $24 \cdot 7$ \\
\hline $\begin{array}{l}\text { Rumen microbial } \mathrm{N} \\
\text { mass }(\mathrm{g} \mathrm{N})\end{array}$ & $120 \cdot 9$ & $88 \cdot 2$ & $127 \cdot 5$ & $108 \cdot 3$ & $102 \cdot 9$ & $100 \cdot 1$ \\
\hline $\begin{array}{l}\text { Duodenal flow of } \\
\text { microbial N (g N/day) }\end{array}$ & $116 \cdot 4$ & $110 \cdot 3$ & $130 \cdot 8$ & $104 \cdot 7$ & $100 \cdot 7$ & $97 \cdot 3$ \\
\hline $\begin{array}{l}\text { Microbial N turnover } \\
\text { (g N/day) }\end{array}$ & $85 \cdot 9$ & $99 \cdot 9$ & $109 \cdot 0$ & $118 \cdot 5$ & $73 \cdot 8$ & $73 \cdot 6$ \\
\hline $\begin{array}{l}\text { Fractional microbial } \mathrm{N} \\
\text { turnover (per day) }\end{array}$ & $0 \cdot 711$ & $1 \cdot 132$ & 0.855 & $1 \cdot 094$ & $0 \cdot 717$ & 0.736 \\
\hline $\begin{array}{l}\text { Microbial N recycling } \\
(\%)\end{array}$ & $42 \cdot 5$ & $47 \cdot 5$ & $45 \cdot 5$ & $53 \cdot 1$ & $42 \cdot 3$ & $43 \cdot 1$ \\
\hline
\end{tabular}

$21 \cdot 0 \mathrm{~kg} \mathrm{DM} /$ day with diet $\mathrm{HC100)}$ (Fig. 2c). The different responses in fractional turnover rate when simulating high-roughage and high-concentrate diets can be explained as follows. Total microbial $\mathrm{N}$ in the rumen (the denominator of Eqn (2)) increased to a higher extent than the turnover of microbial $\mathrm{N}$ on high-roughage diets, whereas the reverse was true for high-concentrate diets. This more rapid increase in $\mathrm{N}$ turnover with increments in daily DMI on highconcentrate diets, is the result of less marked reductions in the proportion of protozoal $\mathrm{N}$ to rumen microbial N (Fig. 2a) and the more rapid increases in protozoal fractional death rate. Fractional passage rates will rise with an increase in daily DMI, and hence microbial $\mathrm{N}$ recycling decreased with elevations in daily DMI, particularly with high-roughage diets (Fig. $2 d$ ). Simulated differences in microbial $\mathrm{N}$ recycling between diets with different concentrate proportions were more pronounced at low daily DMI (59.2 and $40.4 \%$ for diets $\mathrm{HC} 0$ and $\mathrm{HC} 100$ at daily DMI of $5.3 \mathrm{~kg} /$ day, respectively) than at high daily DMI (38.6 and $41.4 \%$ for diet HC0 and diet HC100 at daily DMI of $21.0 \mathrm{~kg} /$ day, respectively).

\section{Effect of type of roughage}

The effects of replacing the hay by maize silage upon simulated ruminal microbial $\mathrm{N}$ turnover and recycling were much more pronounced than when replacing the hay by grass at daily DMI of $9 \cdot 2 \mathrm{~kg} /$ day (Table 4 ) and $17 \cdot 1 \mathrm{~kg} /$ day (Table 5). The moderate starch and low $\mathrm{N}$ content of the maize silage, compared with hay or grass, resulted in enhanced protozoal growth (Dijkstra 1994). Protozoal N amounted to $53 \%$ of total rumen microbial $\mathrm{N}$ with Diet $\mathrm{MC0}$ at daily DMI of
$9 \cdot 2 \mathrm{~kg} /$ day. In comparison, diet MC67 reduced the relative amount of protozoal $\mathrm{N}$ to $33 \%$ at daily DMI 9.2 of $\mathrm{kg} /$ day. The relative amount of protozoal $\mathrm{N}$ mass on diets MC0 and MC67 also declined in response to rises in daily DMI. Outflow of microbial $\mathrm{N}$ from the rumen was lower for maize silage diets than for grass- or hay-based diets, particularly so on the low concentrate diets. Because of the large amount of protozoa simulated with diet $\mathrm{MC} 0$, microbial $\mathrm{N}$ recycling (68.3 and $66.5 \%$ at daily DMI of 9.2 and $17 \cdot 1 \mathrm{~kg} /$ day, respectively) was markedly higher than microbial $\mathrm{N}$ recycling with pure hay or grass diets (between $36 \cdot 3$ and $49 \cdot 1 \%$ ).

\section{Effects of type of concentrate}

The high-protein supplements resulted in relatively small flows of microbial $\mathrm{N}$ from the rumen, whereas simulated microbial $\mathrm{N}$ flows were highest with barley (Tables 6 and 7). Differences in microbial $\mathrm{N}$ turnover and recycling between diets were generally far less pronounced at the higher daily DMIs, as noted previously. In comparison with the reference diet (diet HC67), the protein-rich supplements reduced microbial $\mathrm{N}$ turnover, whereas the soluble sugar- and starch-rich supplements increased turnover. The highest simulated increase was with the maize grain (diet HMG67) at the lower daily DMIs (Table 6), because this starch-rich supplement resulted in a large population of protozoa ( $44 \cdot 2$ g protozoal $\mathrm{N}$ on diet HMG67 v. $28.5 \mathrm{~g}$ protozoal $\mathrm{N}$ on diet $\mathrm{HC} 67)$. The soluble sugar-rich supplement (molasses; diet HML67) resulted in rapid uptake of sugars by protozoa and subsequent protozoal growth, but the intracellular accumulation of acidic fermentation products from 
Table 7. The simulated rumen protozoal nitrogen $(N)$ and total microbial $N$ mass, duodenal microbial $N$ flow, and microbial $N$ turnover and recycling in the rumen of cattle fed hay-concentrate $(1: 2, w / w$; diet HC67), haymolasses-concentrate $(1: 1: 1, w / w$; diet HML67), hay-barley-concentrate $(1: 1: 1, w / w ;$ diet HBA67), hay-maize grain-concentrate $(1: 1: 1, w / w$; diet HMG67), hay-soyabean meal-concentrate $(1: 1: 1, w / w$; diet HSU67) or hayformaldehyde-treated soyabean meal-concentrate $(1: 1: 1, w / w$; diet HST67) at a dry matter intake of $17 \cdot 1 \mathrm{~kg} / \mathrm{day}$

\begin{tabular}{|c|c|c|c|c|c|c|}
\hline & \multicolumn{6}{|c|}{ Diet } \\
\hline & HC67 & HML67 & HBA67 & HMG67 & HSU67 & HST67 \\
\hline $\begin{array}{l}\text { Rumen protozoal } \mathrm{N} \\
\text { mass }(\mathrm{g} \mathrm{N})\end{array}$ & $35 \cdot 9$ & $30 \cdot 5$ & $39 \cdot 3$ & $40 \cdot 5$ & $31 \cdot 5$ & $31 \cdot 8$ \\
\hline $\begin{array}{l}\text { Rumen microbial } \mathrm{N} \\
\text { mass }(\mathrm{g} \mathrm{N})\end{array}$ & $172 \cdot 0$ & $110 \cdot 5$ & $186 \cdot 3$ & $154 \cdot 6$ & $143 \cdot 2$ & $138 \cdot 9$ \\
\hline $\begin{array}{l}\text { Duodenal flow of } \\
\text { microbial } \mathrm{N}(\mathrm{g} \mathrm{N} / \text { day })\end{array}$ & $215 \cdot 1$ & $207 \cdot 8$ & $260 \cdot 8$ & $224 \cdot 8$ & $182 \cdot 6$ & $176 \cdot 3$ \\
\hline $\begin{array}{l}\text { Microbial N turnover } \\
\text { (g N/day) }\end{array}$ & $145 \cdot 0$ & $133 \cdot 0$ & $169 \cdot 0$ & $167 \cdot 0$ & $120 \cdot 5$ & $119 \cdot 9$ \\
\hline $\begin{array}{l}\text { Fractional microbial } \mathrm{N} \\
\text { turnover (per day) }\end{array}$ & $0 \cdot 843$ & $1 \cdot 203$ & 0.908 & $1 \cdot 080$ & 0.842 & $0 \cdot 864$ \\
\hline $\begin{array}{l}\text { Microbial N recycling } \\
(\%)\end{array}$ & $40 \cdot 3$ & $39 \cdot 0$ & $39 \cdot 3$ & $42 \cdot 6$ & $39 \cdot 8$ & $40 \cdot 5$ \\
\hline
\end{tabular}

sugar metabolism caused high protozoal death rates, particularly at the higher daily DMIs.

The amount of rumen available protein is higher with the diet containing untreated soyabean meal (diet HSU67) compared with formaldehyde-treated soyabean meal (diet HST67). The treatment of soyabean meal would be expected to give a competitive advantage to the protozoa, since microbial protein is an important source of amino acids for them, whereas bacteria rely upon feed protein to supply amino acids. However, the protein content of the other feed components (hay and concentrate) was already sufficient for bacterial growth, and therefore treatment of the soyabean meal had little effect on protozoal metabolism and microbial $\mathrm{N}$ turnover and recycling. In comparison with the reference diet, the lower availability of carbohydrates (which are the main source of energy for microbial growth) with diets HSU67 and HST67 resulted in a reduction in the amount and turnover of ruminal microbial $\mathrm{N}$.

\section{DISCUSSION}

The recycling of microbial protein wastes energy and also $\mathrm{N}$ when the released amino acids are deaminated (Hespell \& Bryant 1979). Direct quantifications of microbial $\mathrm{N}$ recycling have been obtained using isotope tracer methods, but the number of studies is few (Nolan \& Leng 1972; Nolan \& Stachiw 1979; Leng \& Nolan 1984; Aharoni et al. 1991; Firkins et al. 1992). Disadvantages of isotope tracer methods include the number of experiments required to obtain reliable estimates, the unrepresentative labelling of samples of microbes, and the difficult biological interpretation of the measured pools and fluxes (Firkins et al. 1992; Firkins 1996). Furthermore, this technique has only been used once under different dietary conditions within the same experiment (Aharoni et al. 1991). The approach in the present study was to quantify microbial $\mathrm{N}$ recycling due to protozoal activities by representing the underlying processes in an integrated model of rumen fermentation.

\section{Turnover and recycling in the rumen}

In the present analysis, microbial $\mathrm{N}$ turnover and recycling was related entirely to protozoal activities. Other factors which contribute to microbial turnover include bacteriophage-mediated lysis of bacterial cells (Klieve \& Bauchop 1988) and lysis due to nutrient starvation (Mink \& Hespell 1981). The quantitative effect of bacteriophages on microbial turnover is unknown. Nutrient starvation is not expected to occur in frequently fed animals as the nutrient supply is almost continuous. In several studies with a number of bacterial species, Selenomonas ruminantium was observed to be in the lowest range of survival times, $50 \%$ of the population grown under glucose-limited conditions being non-viable after $2 \cdot 5 \mathrm{~h}$ (Mink \& Hespell 1981). In the rumen, however, this organism apparently survives prolonged periods of starvation. The presence of storage polysaccharides within the cells will help to enhance survival (Mink \& Hespell 1981). Also, cross-feeding between bacteria in consortia may provide substrates to individual bacteria during the periods of non feeding in infrequently fed animals (McAllister et al. 1994). Other findings suggest 
that the major contribution to microbial turnover relates to protozoal activities. The in vitro disappearance rate of Lactobacillus plantarum in protozoafree incubations was only $6-15 \%$ of the corresponding rate in the control incubations (Sharp et al. 1994). Wallace \& McPherson (1987) observed for a number of bacterial species that protozoa were responsible for $88 \%$ of bacterial protein turnover in vitro. Protein turnover of Selenomonas ruminantium in in vitro incubations with rumen fluid from defaunated sheep was $<10 \%$ of the turnover with rumen fluid from faunated sheep (Newbold \& Hillman 1990). The extensive autolysis of protozoa is well known (Leng 1982; Leng et al. 1984, 1986; Ffoulkes \& Leng 1988; Krebs et al. 1989; Punia et al. 1992). Consequently, the estimated microbial turnover and recycling related solely to protozoal activities, will probably underestimate the total turnover and recycling only to a minor extent.

The availability of starch and sugars has a major impact upon the protozoal population (Jouany 1989). In line with these observations, the simulations indicated relatively large amounts of rumen protozoal $\mathrm{N}$ mass on diets containing high amounts of starch and soluble sugars at low or moderate daily DMIs (Tables 4-7). Simulated fractional death rates of protozoa rapidly increased and protozoal biomass was reduced when daily DMI of these diets was raised. Indeed, protozoal numbers in cattle fed high concentrate diets at high daily DMI are low (Jouany 1989). Unlike bacteria, protozoa utilize both dietary and microbial proteins, and this difference helps to explain the response to changes in dietary $\mathrm{N}$ content. An increase in dietary $\mathrm{N}$ content generally reduced protozoal biomass and increased bacterial biomass (Dijkstra 1994). The simulated protozoal $\mathrm{N}$ mass in the rumen on soyabean meal diets (Tables 6 and 7) was in line with a slightly higher protozoal N-pool due to treatment with formaldehyde (Krebs et al. 1989), because this treatment is expected to reduce ruminal N-availability (Van Straalen \& Tamminga 1990) and therefore reduce the efficiency of microbial protein synthesis (amount of microbial $\mathrm{N}$ formed per unit of organic matter (OM) truly degraded in the rumen). In the simulations, the amount of protozoal $\mathrm{N}$ is a major determinant of microbial $\mathrm{N}$ turnover and recycling. Thus, like rumen protozoal biomass, turnover and recycling were generally seen to increase when dietary sugar contents, and particularly starch contents, were increased, and turnover and recycling were smaller when ruminal $\mathrm{N}$ availability was improved. The highest recycling was simulated on the all-maize silage diet at low daily DMI. This diet promoted protozoal proliferation due to a relatively high amount of starch and a low availability of dietary protein, the latter decreasing the efficiency of bacterial growth (g N synthesised per unit organic matter truly degraded).
Another major factor in microbial $\mathrm{N}$ recycling is rate of passage from the rumen. Amylolytic and cellulolytic bacteria were assumed to be washed out with the fluid and particulate material, respectively, and protozoa at half the particulate passage rate (Dijkstra et al. 1992). It was shown in previous sensitivity analyses that substrate degradation and microbial outflow were sensitive to changes in values of fractional passage rates (Neal et al. 1992). Thus, accurate quantification of microbial $\mathrm{N}$ recycling using the model depends on reliable estimates of fractional passage rates. The accuracy of equations to estimate passage rates is rather low (percentage of variance explained is $61 \%$ or lower; Owens \& Goetsch 1986). The satisfactory prediction of fibre degradation and VFA concentration in the rumen and $\mathrm{N}$ outflow from the rumen on a wide range of diets (Neal et al. 1992) however, indicates that the estimates of fractional passage rates using the Owens \& Goetsch (1986) equations are sufficient for the purposes of this modelling exercise.

Recycling due to predation by and lysis of protozoa

In the model, predation by and lysis of protozoa contribute to microbial $\mathrm{N}$ turnover in the rumen. Predation on micro-organisms by protozoa was represented by Michaelis-Menten equations similar to that of Holling (1959). On a wide range of predator species, Holling's equation has been found to provide a good fit to experimental data (Brown \& Rothery 1993). The ability of rumen protozoa to engulf attached bacteria as compared with bacteria free in rumen fluid is a matter of conjecture. The engulfment of solid feed particles by protozoa is well known (review Williams \& Coleman 1988) and this is expected also to result in the engulfment of bacteria attached to these particles. Alternatively, the attachment of bacteria to plant particles may serve to protect them from protozoal predation. This hypothesis of protection to engulfment by means of attachment, has been supported by observations that upon defaunation, the fluid-phase, non-fibrolytic bacteria increased to a far higher extent than did attached bacteria (Weimer 1992). However, the preference of protozoa for starch and sugars rather than fibre will result in a relative higher availability of starch and sugars compared with fibre upon defaunation and hence a smaller expected increase in attached, fibrolytic bacteria compared with non-attached bacteria.

Protozoal cells do not control their uptake rate of soluble sugars (Williams 1979) and on diets high in easily degradable carbohydrates, protozoa degenerate and burst (Williams \& Coleman 1988). The effect of protozoal death on simulated microbial $\mathrm{N}$ turnover is best illustrated using the diets containing molasses (diet HML67, Tables 6 and 7). At a low daily DMI of diet HML67, hence low substrate availability, simu- 
lated fractional death rate was moderate and the relative amount of protozoal $\mathrm{N}$ was higher than on the reference diet, giving rise to a higher microbial $\mathrm{N}$ turnover. At a high daily DMI, protozoal death rate markedly increased, resulting in a lower protozoal biomass in the rumen compared with diet HC67 and as a result microbial turnover was slightly lower. The model does not represent other factors related to protozoal death. These factors include the presence of lytic agents and toxic chemicals, and the effect of oxygen intake in feed (Coleman 1985; Leng 1989). However, the quantitative contribution of such factors is unknown. The representation adopted in the model provides for sound behaviour with respect to changes in protozoal and bacterial biomass in response to dietary variations (Dijkstra 1994).

\section{Observed and simulated turnover and recycling}

The simulations indicated the effects of dietary variations upon microbial $\mathrm{N}$ turnover and recycling, which help to explain some experimental observations. Nolan \& Leng (1972) and Nolan \& Stachiw (1979) reported $30-50 \%$ recycling of microbial $\mathrm{N}$ on allroughage diets (lucerne chaff or wheaten hay), fed at low daily DMI to sheep. In our simulations, recycling on all-hay and all-grass diets was 49 and $47 \%$ at the lower daily DMI of cattle (Table 4). However, recycling of microbial $\mathrm{N}$ in the experiments of Nolan \& Leng (1972) and Nolan \& Stachiw (1979) was through the ammonia pool only and thus probably represents an underestimation of the total recycling. In our model, recycling through the protein pool has been represented as well. A part of the amino acids or peptides derived from hydrolysis of recycled microbial protein can be incorporated directly into bacterial and protozoal protein, without proceeding through the ammonia pool.

Firkins et al. (1992) realized both routes of microbial $\mathrm{N}$ recycling (via ammonia and nonammonia pools) and evaluated it directly using compartmental analysis. They estimated microbial $\mathrm{N}$ recycling to be $76-90 \%$ of gross microbial synthesis and suggested that, in comparison to methods which determine microbial $\mathrm{N}$ recycling through the ammonia pool only, these higher figures represented ruminal conditions more accurately. However, maize silage formed the major component of the diet used in Firkins et al. (1992) (85\% of total diet DM). The simulation results presented in Table 4 indicate a higher recycling with an all-maize silage diet than with an all-grass or all-hay diet (68v. 49 and $47 \%$ ). This suggests that at least part of the higher microbial $\mathrm{N}$ recycling estimated by Firkins et al. (1992) is related to the diet used in that particular study. The estimate of microbial $\mathrm{N}$ recycling with the all-maize silage diet at DMI of $9 \cdot 2 \mathrm{~kg} /$ day $(68 \%)$ was lower than the estimated recycling on the $85 \%$ maize silage diet reported by Firkins et al. (1992) (76-90\%). Since the estimate of Firkins et al. (1992) includes the contribution of non-protozoal factors towards recycling, the difference might represent a rough indication of the contribution of these factors, such as bacteriophage- and substrate-mediated lysis of microbial cells. As discussed previously, the removal of protozoa reduced bacterial protein breakdown in vitro to a similar extent. Aharoni et al. (1991) distinguished the rumen microbial pool into a small, rapidly turning over pool and a large, slowly turning over pool. The outflow of $\mathrm{N}$ from the slowly turning over microbial $\mathrm{N}$ pool to the ammonia pool, divided by the sum of the fluxes into this slowly turning over pool, estimates microbial $\mathrm{N}$ recycling. On diets containing some $25-30 \%$ straw with soyabean meal as the main source of feed $\mathrm{N}$ and offered to sheep, recycling varied between 22 and $61 \%$. The simulated recycling (between 40 and $43 \%$; Tables 6 and 7) of diets containing $33 \%$ hay and added soyabean meal is well within this range.

\section{Relation between microbial efficiency and recycling in the rumen}

The estimates of recycling reported by Firkins et al. (1992) were higher $(90 \%$ v. $76 \%)$ at lower DMI (4.7 v. $10 \mathrm{~kg}$ /day). Our simulations agree qualitatively with this finding, showing a general decrease in recycling on roughage diets when daily DMI is raised (Fig. 2d). However, this decrease cannot be entirely related to the higher fractional passage rates associated with elevated intake (Owens \& Goetsch 1986). Simulated protozoal $\mathrm{N}$ mass in the rumen, as a fraction of total microbial $\mathrm{N}$, also decreased, therefore contributing to the decrease in microbial turnover. In contrast, simulations with high-concentrate diets indicated a general increase in rumen protozoal $\mathrm{N}$ and protozoal activities when daily DMI increased, causing an increase in microbial $\mathrm{N}$ recycling even though fractional passage rates were also higher. Such changes have important consequences for the efficiency of microbial protein synthesis in response to dietary variations. The impact of turnover of microbial material in the rumen is large, as indicated by the generally improved efficiency of microbial protein synthesis upon defaunation (review Jouany et al. 1988). Re-synthesis of recycled microbial material will require substantial amounts of energy (Hespell \& Bryant 1979), whereas a large part of the synthesised protozoal protein will not pass out to the duodenum. To illustrate the impact of recycling on the efficiency of microbial protein synthesis, consider the amount of $\mathrm{OM}$ used per unit microbial protein flowing from the rumen when recycling is low $(35 \%)$ or high $(75 \%$ of gross synthesis). Assuming that $70 \%$ of the $\mathrm{N}$ requirements to synthesise microbial protein is met by ammonia, the synthesis of $1 \mathrm{~g}$ microbial protein 
requires 3.0 g OM (Dijkstra et al. 1992). To synthesise $1 \mathrm{~g}$ of microbial protein flowing to the omasum at 35 and $75 \%$ recycling, $4.7(1 / 0.65 \times 3.0)$ and 12.1 $(1 / 0 \cdot 25 \times 3 \cdot 0) \mathrm{g}$ OM is utilized, respectively. Thus, diet composition and daily DMI can markedly affect the efficiency of microbial protein synthesis, and application of the model will assist in predicting and explaining variations in recycling and efficiency with dietary changes.

In vitro experiments clearly indicated the positive effect of higher solid or liquid turnover rates upon microbial efficiency in continuous culture (e.g. Isaacson et al. 1975). In these cultures, microbial growth rates increase with higher outflow rates. The fraction of energy spent for non-growth (maintenance) purposes is reduced when growth rate is increased (Pirt 1965), and this explains the increased microbial efficiency. Fractional passage rates generally increase with elevated daily DMI (Owens \& Goetsch 1986), and therefore increased DMI might be expected to improve microbial efficiency. Yet in vivo experiments in which fluid passage rates were increased did not show such a clear relation, sometimes improving microbial efficiency (Harrison et al. 1975; Kennedy \& Milligan 1978), otherwise depressing it (Hadjipanayiotou et al. 1982; Goetsch \& Owens 1985). Equally, curvilinear responses of microbial efficiency to DMI have been reported (reviews Robinson \& Tamminga 1984; Clark et al. 1992). Clearly, other factors such as the change in protozoal activities and related microbial $\mathrm{N}$ turnover, have to be considered. The simulations indicated that turnover and recycling of microbial $\mathrm{N}$ might decrease or increase with changes in daily DMI, dependent upon dietary composition
(Fig. $2 c, d$ ). Thus, the response of microbial efficiency (increase or decrease) to changes in DMI will vary according to the diet. Hence the model simulations can help to quantify and explain variations in microbial recycling in the rumen so as to improve microbial efficiency and ultimately the efficiency of ruminant production.

\section{Conclusion}

In conclusion, an integrated model of rumen fermentation processes provided a coherent holistic view of the contribution of protozoa to turnover and recycling of microbial $\mathrm{N}$ in the rumen. The simulations provided a further understanding of the changes in microbial turnover and recycling in response to dietary variations. It was shown that increases in daily DMI generally reduced microbial $\mathrm{N}$ turnover on highroughage diets, but increased microbial $\mathrm{N}$ turnover on high-concentrate diets. Such differences were related to substrate availability in the rumen and the substrate preferences of protozoa and consequently protozoal activities in the rumen. The predicted response of microbial $\mathrm{N}$ recycling to dietary changes was shown to vary accordingly, with a large impact on the OM required per gram microbial protein flowing to the omasum. Thus, the simulations can help to explain and improve the efficiency of microbial protein synthesis, by quantification of the interactions between microbial populations in the rumen.

The research of J. Dijkstra has been made possible by a fellowship of the Royal Netherlands Academy of Arts and Sciences.

\section{REFERENCES}

Aharoni, Y., Tagari, H. \& Boston, R. C. (1991). A new approach to the quantitative estimation of nitrogen metabolic pathways in the rumen. British Journal of Nutrition 66, 407-422.

Brown, D. \& Rothery, P. (1993). Models in Biology: Mathematics, Statistics and Computing. Chichester: John Wiley \& Sons Ltd.

Clark, J. H., Klusmeyer, T. H. \& Cameron, M. R. (1992). Microbial protein synthesis and flows of nitrogen fractions to the duodenum of dairy cows. Journal of Dairy Science 75, 2304-2323.

Coleman, G. S. (1975). The interrelationship between rumen ciliate protozoa and bacteria. In Digestion and Metabolism in the Ruminant (Eds I. W. McDonald \& A. C. I. Warner), pp. 149-164. Armidale: University of New England Publishing Unit.

Coleman, G. S. (1985). Possible causes of the high death rate of ciliate protozoa in the rumen. Journal of Agricultural Science, Cambridge 105, 39-43.

Coleman, G. S. (1989). Protozoal-bacterial interactions in the rumen. In The Roles of Protozoa and Fungi in Ruminant Digestion (Eds J. V. Nolan, R. A. Leng \& D. I. Demeyer), pp. 13-27. Armidale: Penambul Books.
Coleman, G. S. (1992). The rate of uptake and metabolism of starch grains and cellulose particles by Entodinium species, Eudiplodinium maggii, some other entodiniomorphid protozoa and natural protozoal populations taken from the ovine rumen. Journal of Applied Bacteriology 73, 507-513.

Coleman, G. S. \& SAndFord, D. C. (1979). The engulfment and digestion of mixed rumen bacteria and individual bacterial species by single and mixed species of rumen ciliate protozoa grown in vivo. Journal of Agricultural Science, Cambridge 92, 729-742.

DiJKsTRA, J. (1994). Simulation of the dynamics of protozoa in the rumen. British Journal of Nutrition 72, 679-699.

Dijkstra, J. \& Tamminga, S. (1995). Simulation of the effects of diet on the contribution of rumen protozoa to degradation of fibre in the rumen. British Journal of Nutrition 74, 617-634.

Dijkstra, J., Neal, H. D.St.C., Beever, D. E. \& France, J. (1992). Simulation of nutrient digestion, absorption and outflow in the rumen: model description. Journal of Nutrition 122, 2239-2256.

FAICHNEY, G. J. (1989). Mean retention time and intra- 
ruminal degradation of rumen protozoa. Proceedings of the Nutrition Society of Australia 14, 135.

Ffoulkes, D. \& LenG, R. A. (1988). Dynamics of protozoa in the rumen of cattle. British Journal of Nutrition $\mathbf{5 9}$ 429-436.

FIRKINS, J. L. (1996). Maximizing microbial protein synthesis in the rumen. Journal of Nutrition 126, 1347S-1354S.

Firkins, J. L., Weiss, W. P. \& Piwonka, E. J. (1992). Quantification of intraruminal recycling of microbial nitrogen using nitrogen-15. Journal of Animal Science 70, 3223-3233.

Forsberg, C. W., Lovelock, L. K. A., Krumholz, L. \& Buchanan-Smith, J. G. (1984). Protease activities of rumen protozoa. Applied and Environmental Microbiology 47, 101-110.

France, J. \& Thornley, J. H. M. (1984). Mathematical Models in Agriculture. London: Butterworths.

Goetsch, A. L. \& Owens, F. N. (1985). Effects of calcium source and level on site of digestion and calcium levels in the digestive tract of cattle fed high-concentrate diets. Journal of Animal Science 61, 995-1003.

Hadjipanayiotou, M., Harrison, D. G. \& Armstrong, D. G. (1982). The effects upon digestion in sheep of the dietary inclusion of additional salivary salts. Journal of the Science of Food and Agriculture 33, 1057-1062.

Harrison, D. G., Beever, D. E., Thomson, D. J. \& Osbourn, D. F. (1975). Manipulation of rumen fermentation in sheep by increasing the rate of flow of water from the rumen. Journal of Agricultural Science, Cambridge 85, 93-101.

Hespell, R. B. \& Bryant, M. P. (1979). Efficiency of rumen microbial growth: influence of some theoretical and experimental factors on $\mathrm{Y}_{\mathrm{ATP}}$. Journal of Animal Science 49, 1640-1659.

Holling, C. S. (1959). Some characteristics of simple types of predation and parasitism. Canadian Entomologist 91, 385-398.

IsaAcson, H. R., Hinds, F. C., Bryant, M. P. \& Owens, F. N. (1975). Efficiency of energy utilization by mixed rumen bacteria in continuous culture. Journal of Dairy Science 58, 1645-1659.

JoUANY, J. P. (1989). Effects of diet on populations of rumen protozoa in relation to fibre digestion. In The Roles of Protozoa and Fungi in Ruminant Digestion (Eds J. V. Nolan, R. A. Leng \& D. I. Demeyer), pp. 59-74. Armidale: Penambul Books.

Jouany, J. P., Demeyer, D. I. \& Grain, J. (1988). Effect of defaunating the rumen. Animal Feed Science and Technology 21, 229-265.

Kennedy, P. M. \& Milligan, L. P. (1978). Effects of cold exposure on digestion, microbial synthesis and nitrogen transformations in sheep. British Journal of Nutrition 39, 105-117.

Klieve, A. V. \& BAUChOP, T. (1988). Morphological diversity of ruminant bacteriophages from sheep and cattle. Applied and Environmental Microbiology 54, 16371641.

Krebs, G. A., Leng, R. A. \& Nolan, J. V. (1989). Microbial biomass and production rates in the rumen of faunated and fauna-free sheep on low protein fibrous feeds with or without nitrogen supplementation. In The Roles of Protozoa and Fungi in Ruminant Digestion (Eds J. V. Nolan, R. A. Leng \& D. I. Demeyer), pp. 295-299. Armidale: Penambul Books.
LENG, R. A. (1982). Dynamics of protozoa in the rumen of sheep. British Journal of Nutrition 48, 399-415.

LENG, R. A. (1989). Dynamics of protozoa in the rumen. In The Roles of Protozoa and Fungi in Ruminant Digestion (J. V. Nolan, R. A. Leng \& D. I. Demeyer), pp. 51-58. Armidale: Penambul Books.

LeNG, R. A. \& Nolan, J. V. (1984). Nitrogen metabolism in the rumen. Journal of Dairy Science 67, 1072-1089.

Leng, R. A., Nolan, J. V., Cumming, G., Edwards, S. R. \& Graham, C. A. (1984). The effects of monensin on the pool size and turnover rate of protozoa in the rumen of sheep. Journal of Agricultural Science, Cambridge 102, 609-613.

Leng, R. A., Dellow, D. \& Waghorn, G. (1986). Dynamics of large ciliate protozoa in the rumen of cattle fed on diets of freshly cut grass. British Journal of Nutrition 56, 455-462.

McAllister, T. A., Bae, H. D., Jones, G. A. \& Cheng, K.J. (1994). Microbial attachment and feed digestion in the rumen. Journal of Animal Science 72, 3004-3018.

MinK, R. W. \& Hespell, R. B. (1981). Long-term nutrient starvation of continuously cultured (glucose-limited) Selenomonas ruminantium. Journal of Bacteriology 148, 541-550.

Mitchell, E. L. \& Gauthier, J. (1981). Advanced Continuous Simulation Language. User Guide/Reference Manual, 3rd edition. Concord: Mitchell and Gauthier Ass.

Neal, H. D.St.C., Dijkstra, J. \& Gill, M. (1992). Simulation of nutrient digestion, absorption and outflow in the rumen: model evaluation. Journal of Nutrition 122, 2257-2272.

Newbold, C. J. \& Hillman, K. (1990). The effect of ciliate protozoa on the turnover of bacterial and fungal protein in the rumen of sheep. Letters in Applied Microbiology 11, $100-102$.

Nolan, J. V. \& Leng, R. A. (1972). Dynamic aspects of ammonia and urea metabolism in sheep. British Journal of Nutrition 27, 177-194.

Nolan, J. V. \& Stachiw, S. (1979). Fermentation and nitrogen dynamics in Merino sheep given a low-qualityroughage diet. British Journal of Nutrition 42, 63-80.

Owens, F. N. \& Goetsch, A. L. (1986). Digesta passage and microbial protein synthesis. In Control of Digestion and Metabolism in Ruminants (Eds L. P. Milligan, W. L. Grovum \& A. Dobson), pp. 196-223. Englewood Cliffs: Prentice-Hall.

PIRT, S. J. (1965). The maintenance energy of bacteria in growing cultures. Proceedings of the Royal Society London, Series B 163, 224-231.

Prins, R. A. \& VAn Hoven, W. (1977). Carbohydrate fermentation by the rumen ciliate Isotricha prostoma. Protistologica 13, 549-556.

Punia, B. S., Leibholz, J. \& Faichney, G. J. (1992). Rate of production of protozoa in the rumen and the flow of protozoal nitrogen to the duodenum in sheep and cattle given a pelleted diet of lucerne hay and barley. Journal of Agricultural Science, Cambridge 118, 229-236.

Robinson, J. P. \& Hungate, R. E. (1973). Acholeplasma bactoclasticum $\mathrm{sp}$. n., an anaerobic mycoplasma from the bovine rumen. International Journal of Systematic Bacteriology 23, 171-181.

Robinson, P. H. \& Tamminga, S. (1984). Present knowledge of protein digestion and absorption in ruminants. Ubersichten Tierernährung 12, 119-163. 
Robinson, P. H., Tamminga, S. \& Van Vuuren, A. M. (1986). Influence of declining level of feed intake and varying the proportion of starch in the concentrate on rumen fermentation in dairy cows. Livestock Production Science 15, 173-189.

Robinson, P. H., Tamminga, S. \& Van Vuuren, A. M. (1987). Influence of declining level of feed intake and varying the proportion of starch in the concentrate on rumen ingesta quantity, composition and kinetics of ingesta turnover in dairy cows. Livestock Production Science 17, 37-62.

Sharp, R., Hazlewood, G. P., Gilbert, H. J. \& O'Donnell, A. G. (1994). Unmodified and recombinant strains of Lactobacillus plantarum are rapidly lost from the rumen by protozoal predation. Journal of Applied Bacteriology 76, 110-117.

Van Straalen, W. M. \& Tamminga, S. (1990). Protein degradability in ruminant diets. In Feedstuff Evaluation
(Eds J. Wiseman \& D. J. A. Cole), pp. 55-72. London: Butterworths.

Wallace, R. J. \& Cotta, M. A. (1988). Metabolism of nitrogen-containing compounds. In The Rumen Microbial Ecosystem (Ed P. N. Hobson), pp. 217-249. London: Elsevier Science Publishers.

Wallace, R. J. \& McPherson, C. A. (1987). Factors affecting the rate of breakdown of bacterial protein in rumen fluid. British Journal of Nutrition 58, 313-323.

WeImer, P. J. (1992). Cellulose degradation by ruminal microorganisms. Critical Reviews in Biotechnology 12, 189-223.

Williams, A. G. (1979). The selectivity of carbohydrate assimilation by the anaerobic rumen ciliate Dasytricha ruminantium. Journal of Applied Bacteriology 47, 511-520.

Williams, A. G. \& Coleman, G. S. (1988). The rumen protozoa. In The Rumen Microbial Ecosystem (Ed P. N. Hobson), pp. 77-128. London: Elsevier Science Publishers. 